\title{
Protective Role of Quercetin plus Vitamin C on Infection of Rats with Klebsiella pneumoniae and Pseudomonas aeruginosa
}

\author{
Shaimaa Khazaal Waad ${ }^{1}$, Wurood M. Al-Silaykhee ${ }^{2}$, Hekmet B. Alhmadi², Aiad Gaber Arean² \\ ${ }^{1}$ Histologist, College of Veterinary Medicine, Al Muthanna University/Iraq, ${ }^{2}$ Department of Physiology and \\ Medical Physics; College of Medicine, Al Muthanna University/Iraq
}

\begin{abstract}
This study was performed on fifty adult male laboratory rats (Rattus norvegicus) of $175-200$ grams weights. The animals were randomly allocated into five equal groups of ten rats each. The groups of rats were: First, control group where the animals were fed on a standard diet along the experiment period; the Second and Fourth groups, where also maintained on a standard diet while the Third and Fifth groups were also maintained on a standard diet and they were orally dosed with Quercetin (20 mg) and vitamin C (500 $\mathrm{mg}$ ) daily. Suspension in phosphate buffer solution (PBS) was made for the bacteria and colony forming unit (CFU) count was done after making 10 -folds serial dilutions. The rats of the second and third groups were intramuscularly injected with $16 \times 10^{6}(\mathrm{CFU})$ of Klebsiella pneumoniae while those of fourth and fifth groups were intramuscularly injected with $20 \times 10^{5}$ (CFU) of Pseudomonas aeruginosa. After 48 hours of challenge with bacteria, all the rats of the second group and 4 rats of the third group died. On the other hand, all the rats of fourth group and 3 rats of the fifth group died. The organs of died animals of all groups like the stomach, spleen, liver, and thigh muscle were immediately picked up and weighed after death and well homogenized with (PBS) to obtain counting of (CFU) in the organs mentioned. Passing 3 days later, the survived 6 rats of third group and the survived 5 rats of fifth group were euthanized and their organs were treated as the same as the process mentioned before to gain the organs (CFU) count. The results in this study clarify that the use of Quercetin plus vitamin C has led to increase the survival of rats challenged with bacterial infection and the organs bacterial count of them was significantly less than those rats maintained without supplementation with Quercetin and vitamin $\mathrm{C}$ at $(\mathrm{P} \leq 0.05)$.
\end{abstract}

Keywords; Quercetin, Vitamin C, Pseudomonas aeruginosa, Klebsiella pneumoniae.

\section{Introduction}

Opportunistic microbial pathogens are serious challenging obstacle in fields of human or veterinary medicines and Pseudomonas aeruginosa comes in the queue of these pathogens ${ }^{(1)}$. The other paramount pathogen is Klebsiella pneumoniae which is considered as a major problem in patients who suffer from malignancies and who are dwelling in hospitals ${ }^{(2)}$. Vitamin $\mathrm{C}$ is well proved for its fantastic features in defensing against diseases, protecting and promoting all bodily functions. Of these effects relating to vitamin $\mathrm{C}$ are its role as an antioxidant agent, collagen and bone formation assistant, and assistant in enzymes and coenzymes models ${ }^{(3)}$. In addition, vitamin $\mathrm{C}$ was approved to be protective in different ways and in different systems of the body and it can be gained naturally by consuming different vegetables and fruits especially citrus fruits, berries, tomatoes and others ${ }^{(4)}$. Furthermore, vitamin $\mathrm{C}$ was clearly reported to cause healing, repairing and protection against heavy metals intoxication in the vital organs like liver and kidney of laboratory animals ${ }^{(5)}$.

Polyphenolic compounds are a vast family spreading in the world of plant kingdom and comprise flavonoids as a member of them ${ }^{(6)}$. Quercetin belongs to the family of flavonoids and it is of highly antioxidant capacity ${ }^{(7)}$ and it is fluently found in apples, beans, broccoli and onions in particular ${ }^{(8)}$. The antioxidant potency of quercetin was found to be as four times as that of tocopherol ${ }^{(9)}$. The effects of quercetin were linked to its antioxidant potency and its modulating effects on antioxidant enzymes beside its genomic stability effect 
(10). Vast range of beneficial features of quercetin were reported like anticancer, anti-inflammatory, antiulcer, antibacterial, antiviral, cataract preventing role, cardiovascular system protector and other ${ }^{(11)}$. Quercetin also has a protective role against lipid peroxidation and prevent cellular injury ${ }^{(12)}$. Besides, quercetin was reported to be protective against poisonous compounds and has ameliorating and protective role for the hematological and reproductive aspects of laboratory animals $(13,14)$.

\section{Materials and Method}

\section{- Animals and Diets}

Fifty adult laboratory male rats (Rattus norvegicus) of weights 175 - 200 grams were purchased from a local licensed laboratory medical centre and they were housed in a suitable cages in a very typical laboratory conditions and allocated randomly into five groups of ten rats each. The rats were fed and treated as:

1- Control group, fed and maintained on a standard $\operatorname{diet}(\mathrm{AIN}-93)$ referenced by ${ }^{(15)}$.

2- Second group, fed and maintained on a standard diet.

3- Third group, fed and maintained on a standard diet and they were orally dosed with Quercetin $(20 \mathrm{mg})$ and vitamin C (500 mg) daily. The doses of quercetin and vitamin $\mathrm{C}$ were chosen depending upon LD50 (161 mg/ $\mathrm{kg}$ for quercetin, and $11,900 \mathrm{mg} / \mathrm{kg}$ for vitamin C) as referenced by ${ }^{(16,17)}$ respectively.

4- Fourth group, fed and maintained on a standard diet.

5- Fifth group, fed and maintained on a standard diet and they were orally dosed with Quercetin (20 mg) and vitamin C (500 mg) daily.

\section{- Experimental Challenges}

The protocol of the experiment was continued for one month during which the rats were maintained on standard diets and the treatment with quercetin and vitamin $\mathrm{C}$ was done as mentioned before. After that, the rats of the second and third groups where intramuscularly injected with $16 \times 10^{6}$ (CFU) of Klebsiella pneumoniae. Organs of these animals including spleen, liver, kidney, lung and thigh muscle were homogenized in sterile PBS after being removed and weighed. Viable bacteria number in the organs was obtained by plating on specific agar; BHI agar and the expression of results was the number of CFU/g - tissue. The rats of the fourth and fifth groups were intramuscularly injected with $20 \times 10^{5}$ (CFU) of Pseudomonas aeruginosa. Organs of these animals were processed as before mentioned and viable bacteria number in these organs determined by plating on specific agar plates; cetrimide agar and the expression of results was the number of $\mathrm{CFU} / \mathrm{g}$ - tissue. All plates where incubated for 24 hours at $37 \mathrm{C}^{\circ}$ and the scoring of CFU was done. The bacteria isolates used in this experiment where obtained from Basrah general hospital. Cetrimide agar was prepared according to the manner described by ${ }^{(18)}$.

\section{- Statistical analysis}

At $(\mathrm{P} \leq 0.05)$, ( $\mathrm{t})$ test was used to find out the significant differences among groups by using SPSS program version 20 .

\section{Results and Discussion}

It is obvious from the results shown in tables below that the use of quercetin and vitamin $C$ was very effective against the experimental infection of rats with Klebsiella pneumonia and Pseudomonas aeruginosa bacteria where it causes a significant increase in the survival numbers and ratios of rats (table 1) and a significant decrease in the numbers of bacteria isolated from different rats organs (tables 2 and 3).

Quercetin has been reported and documented by vast numbers of researches to be a very potent against viral, fungal, and bacterial infections beside its beneficial effects on all bodily systems and immunity. One of these studies ${ }^{(19)}$ who mentioned that quercetin has a wide range of antiviral, antibacterial, antioxidant properties. As anti-inflammatory agent in animals, quercetin was found to be very potent against inflammation and has a modulatory effect on the immune system beside boosting immunity as a whole ${ }^{(20)}$. It was found to decrease TNF- $\alpha$ of adipose tissue and nitric oxide generation in obese rats (21). The mechanism of quercetin effects against bacterial infection might be related to its anti-inflammatory role where it has a very strong antioxidant potency and cause increase the secretion of cytokines ${ }^{(22,23)}$.

Vitamin C on the other hand, is well known for its drastic effects against infections such as protozoal, viral and bacterial infections ${ }^{(24)}$. Infections with microbial agents in humans or animal lead to oxidative stress and 
then activation of phagocytes which in turn will cause elevation in reactive oxygen species ROS production ${ }^{(25,}$ 26). These ROS are known to cause damages to the cells and it was found in many cases of infection that vitamin $\mathrm{C}$ contents in macrophages or leukocytes declines severely in cases of infection ${ }^{(27,28)}$. One can exclude that vitamin $\mathrm{C}$ is required as antioxidant in case of infection and it can exert its action throughout its antioxidant effects against ROS beside its boosting role to other immune system compartments $(29,30,31,32)$.

Table (1). Role of quercetin and vitamin $C$ on rats' survival after being challenged with Klebsiella pneumonia and Pseudomonas aeruginosa.

\begin{tabular}{|l|l|l|l|l|}
\hline Groups & $\begin{array}{l}\text { Total rats } \\
\text { number }\end{array}$ & Number of died rats & $\begin{array}{l}\text { Number of survived } \\
\text { rats }\end{array}$ & $\begin{array}{l}\text { Ratio of survived rats } \\
\text { \% }\end{array}$ \\
\hline Control & $\mathbf{1 0}$ & $\mathbf{0}$ & $\mathbf{1 0}$ & $\mathbf{1 0 0}$ \\
\hline $\begin{array}{l}\text { Second } \\
\text { Klebsiella }\end{array}$ & $\mathbf{1 0}$ & $\mathbf{1 0}$ & $\mathbf{0}$ & $\mathbf{0}$ \\
\hline $\begin{array}{l}\text { Third } \\
\text { Klebsiella }+ \text { Vit C and } \\
\text { Quercetin }\end{array}$ & $\mathbf{1 0}$ & $\mathbf{4}$ & $\mathbf{6}$ & $\mathbf{6 0}$ \\
\hline $\begin{array}{l}\text { Fourth } \\
\text { Pseudomonas }\end{array}$ & 10 & $\mathbf{3}$ & $\mathbf{7}$ & $\mathbf{0}$ \\
\hline $\begin{array}{l}\text { Fifth } \\
\text { Pseudomonas }+ \text { Vit C and } \\
\text { Quercetin }\end{array}$ & $\mathbf{1 0}$ & 10 & 0 & $\mathbf{7 0}$ \\
\hline
\end{tabular}

Table (2). The role of Quercetin +vitamin C on the cultured Klebsiella pneumonia bacterial numbers isolated from different rats organs

\begin{tabular}{|c|c|c|c|c|c|c|}
\hline \multirow{2}{*}{ Groups } & \multicolumn{6}{|l|}{ Organs } \\
\hline & Muscle & Lung & Kidney & Liver & Spleen & Stomach \\
\hline Control & $\begin{array}{l}\mathrm{C} \\
0\end{array}$ & $\begin{array}{l}\mathrm{C} \\
0\end{array}$ & $\begin{array}{l}\mathrm{C} \\
0\end{array}$ & $\begin{array}{l}\mathrm{C} \\
0\end{array}$ & $\begin{array}{l}\mathrm{C} \\
0\end{array}$ & $\begin{array}{l}\text { C } \\
0\end{array}$ \\
\hline $\begin{array}{l}\text { Second } \\
\text { Klebsiella }\end{array}$ & $\begin{array}{l}\text { A } \\
62 \times 10^{7}\end{array}$ & $\begin{array}{l}\text { A } \\
27 \times 10^{7}\end{array}$ & $\begin{array}{l}\text { A } \\
40 \times 10^{7}\end{array}$ & $\begin{array}{l}\text { A } \\
9 \times 10^{7}\end{array}$ & $\begin{array}{l}\text { A } \\
16 \times 10^{7}\end{array}$ & $\begin{array}{l}\text { A } \\
12 \times 10^{7}\end{array}$ \\
\hline $\begin{array}{l}\text { Third } \\
\text { Klebsiella }+ \text { Vit C and } \\
\text { Quercetin }\end{array}$ & $\begin{array}{l}\text { B } \\
15 \times 10^{6}\end{array}$ & $\begin{array}{l}\text { B } \\
7 \times 10^{6}\end{array}$ & $\begin{array}{l}\text { B } \\
10 \times 10^{6}\end{array}$ & $\begin{array}{l}\text { B } \\
27 \times 10^{6}\end{array}$ & $\begin{array}{l}\text { B } \\
24 \times 10^{6}\end{array}$ & $\begin{array}{l}\text { B } \\
16 \times 10^{6}\end{array}$ \\
\hline
\end{tabular}


Table (3). The role of Quercetin +vitamin C on the cultured Pseudomonas aeruginosa bacterial numbers isolated from different rats organs

\begin{tabular}{|c|c|c|c|c|c|c|}
\hline \multirow{2}{*}{ Groups } & \multicolumn{6}{|l|}{ Organs } \\
\hline & Muscle & Lung & kidney & Liver & Spleen & Stomach \\
\hline Control & $\begin{array}{l}\mathrm{C} \\
0\end{array}$ & $\begin{array}{l}\mathrm{C} \\
0\end{array}$ & $\begin{array}{l}\mathrm{C} \\
0\end{array}$ & $\begin{array}{l}\mathrm{C} \\
0\end{array}$ & $\begin{array}{l}\mathrm{C} \\
0\end{array}$ & $\begin{array}{l}\mathbf{C} \\
0\end{array}$ \\
\hline $\begin{array}{l}\text { Fourth } \\
\text { Pseudomonas }\end{array}$ & $\begin{array}{l}\text { A } \\
37 \times 10^{7}\end{array}$ & $\begin{array}{l}\text { A } \\
25 \times 10^{7}\end{array}$ & $\begin{array}{l}\text { A } \\
31 \times 10^{7}\end{array}$ & $\begin{array}{l}\text { A } \\
8 \times 10^{7}\end{array}$ & $\begin{array}{l}\text { A } \\
13 \times 10^{7}\end{array}$ & $\begin{array}{l}\text { A } \\
11 \times 10^{7}\end{array}$ \\
\hline $\begin{array}{l}\text { Fifth } \\
\text { Pseudomonas + Vit C } \\
\text { and Quercetin }\end{array}$ & $\begin{array}{l}\text { B } \\
13 \times 10^{6}\end{array}$ & $\begin{array}{l}\text { B } \\
6 \times 10^{6}\end{array}$ & $\begin{array}{l}\mathrm{B} \\
8 \times 10^{6}\end{array}$ & $\begin{array}{l}\text { B } \\
21 \times 10^{6}\end{array}$ & $\begin{array}{l}\text { B } \\
21 \times 10^{6}\end{array}$ & $\begin{array}{l}\text { B } \\
14 \times 10^{6}\end{array}$ \\
\hline
\end{tabular}

Ethical Clearance: The Research Ethical Committee at scientific research by ethical approval of both environmental and health and higher education and scientific research ministries in Iraq

Conflict of Interest: The authors declare that they have no conflict of interest.

Funding: Self-funding

\section{References}

1- Tamura Y, Tanaka S. Effect of Calcium Chloride on Experimental Infection of Mice with Pseudomonas aeruginosa. Infection and immunity. 1985; 648651.

2- Cross A. Klebsiella, In S. J. Cryz, Jr. (ed.), Vaccines and immunotherapy. Pergamon Press, New York. 1991; 178-185.

3- Carr A, Frei B. Towards a new recommended dietary allowance for vitamin $\mathrm{C}$ based on antioxidant and health effects in humans. Am J Path. 1991; 18: 499.

4- Henson E, Block G, Levine M. Ascorbic acid: biological functions and relation to cancer. J Nat Cancer Ins. 1991; 83: 547-550.

5- Al-Uboody WSH, Al-Diwan MA, Ishraq J H. Effect of acute exposure of lead acetates on the morphology of liver and kidney of mice (Mus musculus) and the role of vitamin $\mathrm{C}$ as a repairing agent. Bas.J.Vet.Res. 2011; 10(1): 43-55.
6- Vidhya A, Indira M. Protective effect of quercetin in the regression of ethanol-induced hepatotoxicity. Indian J Pharm Sci. 2009; 71: 527-532.

7- Paolillo R, Romano, Carratelli C, Rizzo A. Effect of resveratrol and quercetin in experimental infection by Salmonella enteric serovar Typhimurium. Int Immunopharmacol. 2011; 11: 149-156.

8- Pandey B, Ibrahim R. Current understanding of dietary polyphenols and their role in health and disease. Curr Nutr Food Sci. 2009; 5: 249-263.

9- Sangai P, Verma J. Quercetin ameliorates bisphenol a-induced toxicity in mice. Acta Poloniae Pharmaceutica - Drug Research. 2012; 69(3): 557563.

10- Tieppo J, Vercelino R, Dias S, Silva V, Silveira R, Marroni A. Evaluation of the protective effects of quercetin in the hepatopulmonary syndrome. Food Chem Toxicol. 2007; 45: 1140-1146.

11- Reutrakul C, Ningnuek N, Pohmakotr M. Planta Med. 2007; 73- 683.

12- Inal E, Akgun A, Kahraman A. Radioprotective effects of exogenous glutathione against wholebody gamma-ray irradiation: age- and genderrelated changes in malondialdehyde levels, superoxide dismutase and catalase activities in rat liver. Methods Find Exp Clin Pharmacol. 2002; 24:209-12. 
13- Al-Uboody WS, Al-Diwan MA. Ameliorating and protective role of quercetin against o-anisidine toxicity on some reproductive aspects of laboratory male rats (Rattus norvegicus). Bas.J.Vet.Res. 2015; 14(1): 250-261.

14- Al-Uboody WS, Al-Diwan MA. Study the protective role of quercetin against o-anisidine toxicity on some hematological parameters of laboratory male rats (Rattus norvegicus). Bas.J.Vet.Res. 2015; 14(1): 262-273.

15- Norlin JB. Nutrient requirements of laboratory Animals. Fourth revised editition, National academy press, USA. 1995; 11-58.

16- Duke JA. Handbook of Biological Active Phytochemicals \& Their Activity. Library of congress cataloging-in-publication. CRC press, California. 1992; 139.

17- Cayman chemical. L-Ascorbic acid, safety data sheet. 2018.

18- Brown V I, Lowbury E J L. Use of an improved cetrimide agar medium and other culture methods for Pseudomonas aeruginosa. J. Clin. Path.1965; 18:752.

19- Li Y, Yao J, Han C, et al. Quercetin, inflammation and immunity. Nutrients. 2016; 8(3): 167.

20- Morikawa $\mathrm{K}$, Nonaka $\mathrm{M}$, Narahara $\mathrm{M}$, et al. Inhibitory effect of quercetin on carrageenaninduced inflammation in rats. Life Sci. 2003; 74: 709-721.

21- Rivera L, Morón R, et al. Quercetin ameliorates metabolic syndrome and improves the inflammatory status in obese Zucker rats. Obesity. 2008; 16: 2081-2087.

22- Jung J, Kang J, Kim H. Effect of quercetin on impaired immune function in mice exposed to irradiation. Nutr. Res. Pract. 2012; 6: 301-307.

23- Liu H, Zhang L, Lu S. Evaluation of antioxidant and immunity activities of quercetin in isoproterenoltreated rats. Molecules. 2012; 17: 4281-4291.

24- Hemila H. Vitamin $\mathrm{C}$ and infections. Nutrients. 2017; 9(4): 339.

25- Segal AW. How neutrophils kill microbes. Annu. Rev. Immunol. 2005; 23: 197-223.

26- Akaike $T$. Role of free radicals in viral pathogenesis and mutation. Rev. Med. Virol. 2001; 11: 87-101.

27- Peterhans E. Oxidants and antioxidants in viral diseases. J. Nutr. 1997; 127: 962S-965S.

28- Wang Y, Russo T, Kwon O, et al. Ascorbate recycling in human neutrophils: Induction by bacteria. Proc. Natl. Acad. Sci. 1997; 94: 13816-13819.

29- Nualart F, Rivas C, Montecinos V, et al. Recycling of vitamin $\mathrm{C}$ by a bystander effect. J. Biol. Chem. 2003; 278: 10128-10133.

30- Buffinton G, Christen S, Peterhans E, Stocker R. Oxidative stress in lungs of mice infected with influenza A virus. Free Radic. Res. Commun. 1992; 16: 99-110.

31- Jabbar A A, Al Uboody WSH, Waad S K, Abbas M Q. Physiological Study about the Hematological Effects of Rosuvastatin and Lovastatin as Compared with Sophoretin in Rats (Rattus Norvegicus). Journal of Global Pharma Technology. 2018; 10(08):314-318.

32- Hashim WS, Mshary GS, Al-Samawy ERM, Waad SK. Physiological Study about Rosuvastatin and Lovastatin as Compared with Quercetin in Rats (Rattus norvegicus). Journal of Global Pharma Technology. 2019; 11(05):28-32. 